\title{
UnA RELACión SIMBiótica ENTRE La SANTA Muerte y El NiÑo DE LAS SUERTES
}

\author{
Judith Katia Perdigón Castañeda
}

\begin{abstract}
Resumen: Una tradición en la Ciudad de México que se repite cada año es vestir al Niño Dios hogareño, con el fin de llevarlo a bendecir para la festividad del Día de la Candelaria; los atuendos que se le colocan se vinculan con la devoción a un santo, con la advocación de Jesucristo o con una representación famosa por sus milagros. Un vestido con alta demanda es el del Niño de las Suertes, representación iconográfica que reposa sobre un cráneo a manera de almohada. Esta imagen ha sido retomada y reconceptualizada de manera simbiótica por los creyentes de La Santa Muerte, quienes visten a sus propios Niños Dios con esta alegoría, de tal forma que continúan con la tradición de la celebración de la Candelaria, pero de manera peculiar.
\end{abstract}

Palabras clave: Santa Muerte, Niño de las Suertes, Candelaria.

Enviado a dictamen: 13 de febrero de 2008. Aprobación: 31 de mayo de 2008.

Judith Katia Perdigón Castañeda, licenciada en Restauración de Bienes Muebles por la Escuela Nacional de Conservación, Restauración y Museografía "Manuel del Castillo Negrete" del INAH, maestra en Antropología Social por la Escuela Nacional de Antropología e Historia, restauradora perito de la Coordinación Nacional de Conservación del Patrimonio Cultural del INAH. Temas de especialización: Santa Muerte, monjas coronadas, conservación de textiles, Niño Dios; correo electrónico: paraloidmx@yahoo.com.mx; kperdigon.cncpc@inah.gob.mx.
Abstract: A yearly tradition in Mexico City is to dress the Christ Child at home in order to take it for a blessing on the celebration of Candelaria day; the clothes are related to the devotion to a saint, the invocation of Jesus Christ or any other famous saintly representation because miracles. A dress in high demand is the one of the Lucky Christ Child, an iconographic representation that rests on a skull in the manner of a pillow. This image has been reconsidered and reconceptualized in a symbiotic way by the believers of the Santa Muerte, who dress their own children like the Christ Child, in a style so that they continue with the tradition of celebrating the Candelaria's festivity in its own peculiar way.

Key words: Santa Muerte, Niño de las Suertes, Candelaria.

\section{La celebración de la fiesta de la Candelaria en la Ciudad de México}

C ada año el calendario litúrgico ${ }^{1}$ de la Iglesia Católica marca dos grandes celebraciones que agrupan los misterios de la fe: la Navidad y la Pascua, relacionadas ambas con un sólo acontecimiento: la vida de Jesucristo. La primera celebración trata de la encarnación del Hijo de Dios, que comienza desde su nacimiento en Belén y culmina con la presentación en el templo, temporada que se inicia con el solsticio de invierno y culmina hasta el segundo mes del siguiente año. El otro momento importante se establece en la 
primavera; se trata de la pasión, muerte y resurrección que se celebra en la Semana Santa (Maccono, 1941). De esta forma, el calendario sagrado reproduce indefinidamente los acontecimientos de la existencia de Cristo; cada año recomienza el tiempo con su nacimiento y muerte, persiguiendo un fin transhistórico: la salvación del hombre (Eliade, 1994).

Después de la conmemoración del nacimiento de Jesús y la adoración de los Reyes Magos, una de las fiestas con más arraigo popular según el calendario litúrgico es la del dos de febrero o Día de la Candelaria. Se recuerda que una vez cumplidos los ocho días después de haber sido circuncidado, al niño le pusieron por nombre Jesús, según le había ordenado el ángel a la Virgen María cuando se le apareció antes de que fuese concebido el Hijo de Dios. Y cuando se cumplieron los días de su purificación conforme la ley de Moisés, José y María trajeron a Jesús a Jerusalén para presentarlo ante el Señor (San Lucas, 2: 21-22).

Esto representa un acontecimiento importante en el ciclo religioso católico, ${ }^{2}$ que renueva anualmente uno de los mitos fundamentales de la infancia de Jesús. El Día de la Candelaria o de la Purificación se celebra la liturgia de la presentación de la Virgen María al templo el dos de febrero, 40 días después del nacimiento de Jesús. Esta fiesta tuvo inicialmente un carácter penitencial y purificatorio; las personas se acercaban al sacramento de la penitencia o hacían procesiones con velas encendidas. Con el tiempo, esta celebración presentó algunos cambios, pues los padres de familia acercaron a sus hijos pequeños para que recibieran una bendición. Más tarde se hizo más hincapié en la presentación de la escultura del Niño Jesús que en la purificación de María (Aguilar, 2007: 2).

De esta manera, la religión como fenómeno histórico surgido del desarrollo institucional y mitológico-ritual en torno a los dioses ejerce un compromiso entre el mito y la realidad cotidiana, en la que también se establece un compromiso con la existencia. En esta festividad sucede un fenómeno de capital importancia: la presencia viva de Dios, que goza no sólo de una realidad subjetiva, sino de una cierta autonomía. La escultura de Dios antropomorfo, gracias a la institución eclesiástica, asegura relaciones de intercambio, compromiso, seguridad y beneficio. Es el hombre quien le sirve, le alimenta, le ofrece sacrificios, le canta alabanzas y le dirige sus plegarias para que, en contraparte, estas esculturas sacralizadas:

Le aseguren sustento, éxito, protección, victoria e inmortalidad. El mito, el rito, la magia y la religión garantizan un compromiso, no sólo con el medio ambiente exterior, sino también con las potencias zoológicas, un compromiso interno, en el interior del espíritu humano, con sus propios fantasmas, su propio desorden, su propia ubris, sus propias contradicciones, su propia naturaleza en crisis (Morín, 2005: 168-169).

En México, la fiesta ${ }^{3}$ se ha caracterizado desde hace varios años por la presentación de la imagen del Niño Dios ${ }^{4}$ en el templo para que sea bendecida, junto con algunas velas, flores y los niños ${ }^{5}$ de la familia. Sin embargo, en la Ciudad de México, cosmopolita y moderna, es donde se lleva a cabo, desde hace varios años, un asombroso acto de fe. No se sabe desde cuándo o quién inventó esta forma particular de presentar la figura del Niño Jesús casero en el templo para su bendición, pero en este evento las esculturas son vestidas para la ocasión, sea por el dueño de la imagen o por la madrina asignada desde el arrullo de la celebración de la Navidad. ${ }^{6}$ Las vestiduras suelen cambiarse anualmente por otras nuevas. Es posible que se trate de una herencia medieval que se tejió en el mundo rural, donde el cuerpo no era tratado de la misma forma que en la cultura de la Iglesia. En este caso se vestía al objeto de devoción para hacerlo aceptable, en especial en el culto a los santos como intercesores indispensables (Gélis, 2005: 29).

Esta festividad, en la que es importante "mandar a vestir a la criatura", tiene una gran importancia no sólo por saldar el compromiso entre compadres y afianzar 
lazos de amistad, familiaridad y correspondencia mutua, sino porque puede tratarse de una manda o promesa hecha al Niño Jesús. Así la festividad tiende a originar vínculos de obligación con la imagen y de ésta, por ende, con la familia; el compadrazgo es una oportunidad para reforzar lazos de vecindad y de amistad, en el que se demuestra el respeto que se tiene por una persona determinada o por la imagen del Niño Dios (Perdigón, 1999: 112).

Para cubrir esta demanda de la época festiva, suelen salir a la venta diversos materiales para fabricar ropa y accesorios; abundan los letreros en mercados de la capital con la leyenda: "se visten Niños Dios"; también existen tiendas especializadas en este tipo de indumentaria, ${ }^{7}$ todo el año, o bien hay personas que elaboran a mano la ropa para estas esculturas. Este arte cultivado por muchos (por devoción o por ganarse unos pesos más) se efectúa con tal esmero que hay quienes incluso le muestran al cliente catálogos de santos y de niños Dios, ${ }^{8}$ si no es que ya tienen algunos modelos expuestos en el local de venta con el fin de que la gente escoja cómo quiere que se vista al Niño.

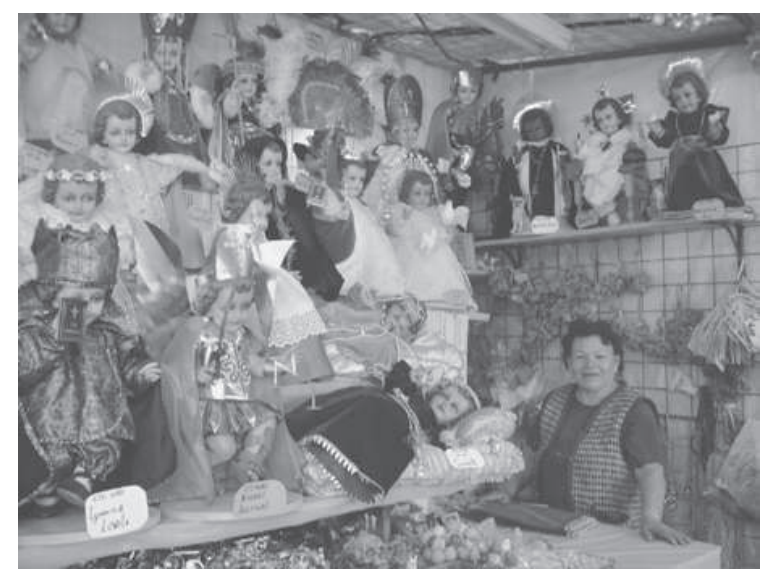

En algunas familias existen fórmulas para vestir al Niño según la tradición: el primer año se le viste de bebé o directamente de "Niño de las Palomas" y se lleva a bendecir acostado en un canasto; en el segundo año se viste de "Niño de las Palomas" o bien de las "Azucenas"; en el tercer año, que es cuando se sienta, se le puede vestir de "Niño de los Borreguitos" o del "Santo Niño de Atocha". Después se le puede parar sobre una peana, vestir como alguna advocación de Jesucristo, de santo, de ángel, de jerarca de la Iglesia o con trajes mundanos que pueden ser incluso de estilo deportivo. ${ }^{9}$ Cabe destacar que actualmente se tiene un registro de aproximadamente 120 modelos, que van desde los trajes tradicionales hasta los de reciente creación, y la tipología de esta indumentaria se relaciona con una etapa de la infancia o adultez de Jesús, con las advocaciones mexicanas y extranjeras a las que se tiene una especial devoción, con vírgenes o elementos relacionados con la liturgia católica y componentes mundanos.

Es interesante cómo, con el paso de los años, la indumentaria ha sufrido modificaciones de acuerdo con modas, réplicas de imágenes milagrosas o adecuaciones a la cultura popular urbana. Además, se tejen nuevas historias a partir de que surge un santo o cuando se incrementa la fama de un Niño Dios milagroso.

Tal es el caso del Santo Niño de las Suertes, escultura que se venera en Tacubaya, Ciudad de México, desde 1937 aproximadamente. Desde hace más de 15 años, su atuendo es altamente estimado en el circuito comercial para la festividad de la Candelaria. Muchas mujeres quieren vestir a su niñito casero como esta imagen porque "es muy milagrosa o trae buena suerte para ganar dinero en los juegos de azar". Pero también hay un sector devocional relacionado con La Santa Muerte que empieza a adjudicarse este símbolo de una manera particular, continuando con la costumbre de la festividad de la Candelaria.

\section{El Niño de las Suertes}

El Santo Niño de las Suertes ${ }^{10}$ es una escultura en madera policromada de una sola pieza datada en el siglo XIX, según el reporte de su aparición en el pueblo de Tlalpan, en la ciudad de México; es una imagen de un 
niño de aproximadamente cuatro meses de edad, con tez blanca, ojos cerrados, recostado lateralmente. Tanto su cabeza como sus brazos reposan sobre una calavera que le sirve de almohada.

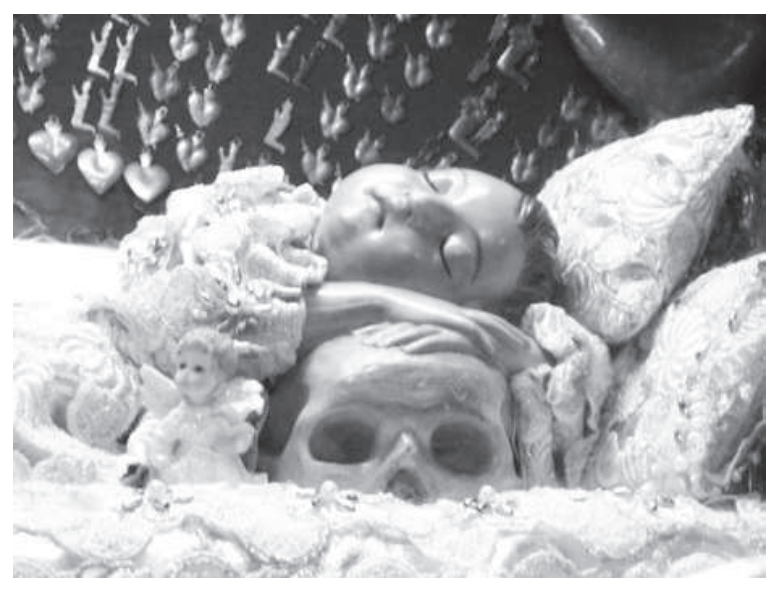

La escultura es una representación del Niño Jesús en una de sus muchas premoniciones con respecto a su futura pasión y muerte, ya que reposa la cabeza sobre una calavera a manera de almohada, aunque también se puede pensar que con ella se hace alusión al Triunfo de la Muerte (Monterrosa y Talavera, 2006: 48).

Es posible que se trate de una alegoría asociada con los Evangelios Apócrifos del Nuevo Testamento, tal como ocurrió en varios ejemplos del arte cristiano y el catolicismo." Es importante mencionar que el catolicismo tiende a acentuar una "visión beatífica" de la muerte crística, deslizándose sobre los tormentos de la Pasión. Esta representación no es más que Jesús sumido en el momento de su muerte.

La muerte de Cristo ofrece un apoyo imaginario a la angustia catastrófica irrepresentable propia de los melancólicos. Sabemos hasta qué punto la fase denominada "depresiva" es esencial para la entrada del niño en el orden de los símbolos y en el de los signos lingüísticos. Esta depresión-tristeza de la separación como condición para la representación de toda cosa ausente repercute sobre y acompaña a nuestras actividades simbólicas cuando no es la exaltación, su envés, lo que las recubre (Kristeva, 1990: 270).

Específicamente al apartado de "Apócrifos de la infancia”, según el Evangelio árabe de la infancia, explica que "entonces Jesús intervino y dijo a su madre: madre mía, de aquí a treinta años me han de crucificar los judíos en Jerusalén y estos dos ladrones serán puestos en cruz juntamente conmigo" (Santos de Otero, 1999: 316). Es importante aclarar que desde el siglo XVII el tema del Niño Jesús ha sido objeto de meditación, pero "su exigencia no les lleva a poner de relieve los encantos de la infancia, sino a descubrir que en el Niño Jesús se anuncia ya la Pasión de Cristo: el sacrificio de Dios hecho carne que acepta morir para salvar a los hombres y, para ello, humillarse siendo niño" (Gélis, 2001: 51).

Para las religiosas concepcionistas del Convento del Dulce Nombre de María y San Bernardo ${ }^{12}$ la imagen representa la omnipresencia de Dios: "Causa gran admiración cómo, en un ser tan pequeñito, tan inofensivo, se desarrolle tanta grandeza para los seres humanos [...] la calaverita representa a la humanidad, se trata de una redención hacia nosotros".

En otras palabras, es la humanidad unida a la divinidad: se trata de cómo el Hijo de Dios vence a la muerte para poder resucitar y glorificar al Padre. Así, el niñito está redimiendo a la humanidad: que los hombres resuciten, que no se queden en el pecado, en la muerte espiritual.

Según una entrevista con el padre José de Jesús Aguilar, esta santa imagen:

Representa al niño dormido y recostado sobre un cráneo humano. Es una imagen simbólica que representa el dominio de Cristo sobre la muerte. Durante el período barroco se crearon imágenes del Niño Jesús en las que se podía prefigurar su pasión, muerte y resurrección. 
Así podemos ver imágenes del Niño Jesús con la cruz o crucificado, o bien con alguna espina en el pie o en la mano e incluso con corona de espinas en la cabeza. La imagen del Niño de las Suertes representaría a Cristo durmiendo, haciendo alusión al descanso en el sepulcro después de su pasión, descanso que terminaría con la resurrección y triunfo sobre la muerte.

Los datos obtenidos en las entrevistas a las religiosas arrojan el concepto del Triunfo de la Cruz:

En el Nuevo Testamento se menciona a la muerte como uno de los mayores males, y será el último enemigo que Cristo someta el día de su segundo advenimiento. Si bien Jesús murió por nuestros pecados (de acuerdo con la teología paulina), al final de los tiempos, cuando se haga extensiva a todos la resurrección, se habrá alcanzado el triunfo sobre la muerte (Perdigón, 2002: 38).

Este concepto se reitera en la instrucción que las hermanas dan a la feligresía que visita la capilla, pero además puede leerse en la novena que se refiere a esta imagen devocional. Incluso está presente en la oración del enfermo que expresa: "Oh Jesús, que al hacerme hombre quisiste sufrir y morir por los hombres y alcanzaste el triunfo sobre el pecado, el dolor y la muerte, acudo a ti lleno de confianza".

Esta imagen religiosa es un ícono que parte de un fenómeno que los hombres no entienden desde su propia existencia y devenir histórico: la muerte, un proceso al que aun hoy se teme: "No entendemos sus causas, ni soportamos emocionalmente sus efectos. Pero como existe, la sociedad tiene que representarla de algún modo, de forma que sólo le queda utilizar signos metonímicos para hacerlo" (Almudena, 2002:54).

A esta santa imagen se le pide todo tipo de milagros relacionados con la salud, el trabajo e incluso el amor. Entre las historias que se cuentan está la de que su semblante cambia de rosado a pálido debido al estado de ánimo de la imagen, "quizá sea porque está triste por la humanidad", dicen las monjas.

Entre los devotos se cuenta que el Santo Niño ha aparecido encarnado, habló con las personas para salvarles, en la cabecera de la cama de un hospital, dio apoyo a un migrante cuando trataba de pasar la frontera norte o incluso se ha mostrado ante los vecinos cercanos al nuevo convento en construcción; las religiosas dicen que de él se obtiene ayuda material y espiritual. A cambio, la feligresía ofrece plegarias, exvotos, milagritos, ropa, juguetes o flores para saldar su deuda o bien para pedir un milagro.

Los comportamientos que se siguen y en los comportamientos a que da lugar el milagro acoge el pasado y la tradición tanto sobre el plano estrictamente religioso como sobre el antropológico, y repropone su lenguaje agregándole la novedad que le da una nueva vida, lo valoriza, le descubre el significado y el sentido (Gemo y Gioia, 1998: 87).

De esta manera, lo ocurrido es un acontecimiento maravilloso, en el cual hay una intervención sobrenatural para obtener un fin religioso o moral, en el curso ordinario de la naturaleza (Royston, 2005: 313).

A la pequeña capilla acuden diariamente personas de todo tipo a conocer o a rogar al Santo Niño. Proceden de diferentes lugares del país y del extranjero; se desplazan sin importar sexo, edad o condición social. Pocas veces interactúan entre ellas, pero sí lo hacen con las religiosas de la tienda, quienes fungen como asesoras espirituales y tienen el cometido de acrecentar la fe de los devotos. Así se cumple con lo estipulado por la Iglesia católica en el sentido de que el culto es para honrar debidamente a Dios, aunque sea privado; "basta que el cristiano haga, según su querer y gusto, actos de reverencia a Dios, los cuales sin embargo, no han de contener nada contra de las enseñanzas de Jesucristo y las prescripciones de la Iglesia" (Maccono, 1941: 8-9). 


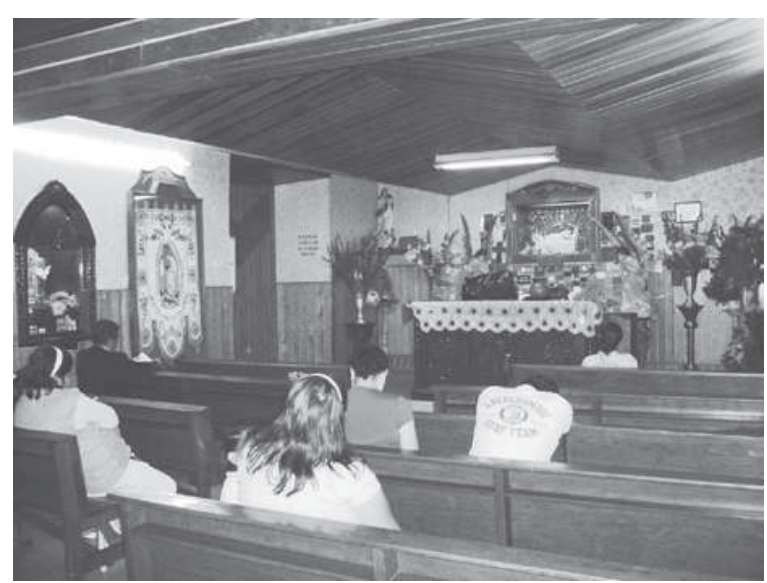

Pero también se han visto personajes singulares que portan medallas, anillos, aretes y muestran tatuajes de La Santa Muerte. Ellos van a orar frente a la imagen del Niño de las Suertes, y no siempre aceptan que se les encamine en el conocimiento de la imagen. Para la actual abadesa, estos personajes llegan por populismo:

Tanto adoran a la Santa Muerte como a la imagen del Santo Niño. Aquí se les pregunta por su devoción a la Santa Muerte ipor qué?, isi no existe! Entonces te platican sobre los milagros de la Santa Muerte. Y les preguntamos za qué atribuyes lo que tú crees? [...] Entonces cuando les explicas la devoción del Santo Niño, lo que significa la calaverita que trae, la humanidad unida con la divinidad, que Dios nos está redimiendo, entonces cambia todo el contexto. Yo creo que la gente tiene que saber la explicación para que puedan constatar. Pero la gente a veces no es capaz de descubrir [...] Les explicamos que la muerte no es santa, que mueras santamente es diferente. Entonces mucha gente se disgusta con nosotras. Cuando se les explica, a veces se quedan como pasmados, muchas veces no escuchan [...] A veces cuando les platicamos que la calaverita es que Jesús la venció, resucitó al tercer día, traspasó las fronteras de la muerte, entonces la gente cambia, se quita la medalla de la Santa Muerte.
Pero si no conocen, no entienden; entonces no cambia nada, se quedan con su creencia.

Los devotos de la Santa Muerte tienen decisión propia sobre su creencia y fe, así como su particular modo de ver su realidad. Ellos deciden seguir adelante con Cristo, la Santita o con ambos, "ipara bien o para mal!".

\section{La Santa Muerte y sus devotos}

La devoción a La Santa Muerte puede ser comprendida como religiosidad popular, la cual "se define a partir de la religión oficial como perteneciente a los grupos populares, subalternos o marginados, en una relación de clase, poder y dominación" (Quezada, 2004: 9); es popular ${ }^{13}$ en tanto que es una expresión del pueblo al que cohesiona y otorga identidad; conformada por elementos de diversas tradiciones culturales: imagen iconográfica europea ${ }^{14}$ y concepto occidental, ofrecimientos (alcohol, tabaco y collares de colores, por citar algunos) de influencia africana y fervor de apropiación, sentimiento y obligación mexicanos. De esta forma se crea una tradición basada en prácticas de naturaleza ritual o simbólica, que surgen o se instituyen dentro de un periodo breve y específico (Rostas y Droogers, 1995).

Los devotos de La Santa Muerte, quienes proceden de distintos puntos de la ciudad, son individuos que han adoptado la imagen esquelética de ésta con vestimenta a la usanza grecolatina y la han santificado de manera popular. "Su representación actual es el resultado de una interesante mezcla de antiguas idiosincrasias y modernas definiciones de fe" (Perdigón, 2002: 37). Los creyentes de esta imagen combinan sin ningún problema distintos rituales e íconos, a fin de concebir un mayor poder en ella, los cuales pueden estar apegados al catolicismo, con elementos prestados de algún santo o virgen ${ }^{15}$ e incluso se les fusiona elementos de la santería, se les coloca materiales de origen prehispánico o de los indígenas de Norteamérica. De alguna manera, cada individuo retoma lo que más le conviene o es cercano a 
su formación familiar, incluso al tipo de vida que lleva; cuando se acerca a algún líder espiritual ${ }^{16}$ adopta las costumbres de éste; se reinterpreta o complementa como creyente.

Sea cual fuere el clan al que pertenezcan, esta imagen funge para los creyentes como símbolo de identidad y elemento adivinatorio; pero sobre todo se trata de un mecanismo de defensa frente a los peligros que otorga la modernidad: "Ser devoto de la Santa Muerte es acercarse a Dios [...] Representa un ángel que hace favores especiales para nosotros y transmite las oraciones al padre eterno para que puedan ser escuchadas".

Los devotos son aquellos que ya no creen en las fórmulas tradicionales de las religiones católica, cristiana, evangélica y sus variantes. Ante las tranzas, negocios, usura, hipocresía, racismo ${ }^{17}$ y otras vejaciones necesitan de algo que los aliente, sin necesidad de intermediarios, ni formulismos cuadrados, y ésta es la razón del atractivo de la Santa Muerte. Esta creencia ha perdurado por varios años y traspasó ya la frontera del siglo XXI. Los creyentes de hoy están entregados a la incertidumbre y al azar de la Ciudad de México y su moderna sociedad, la cual está sometida a una situación de riesgo generalizado, a una sensación de descontrol:

En esta situación de crisis y pérdida de control y rumbo, crecen la incertidumbre y la sensación de desorden, que facilitan la aparición fascinante y ciega del azar. El hombre de fin de siglo se siente entregado de nuevo en brazos de lo indisponible; experimenta de nuevo su contingencia y finitud. El destino, el azar, la fortuna, hacen de nuevo aparición como nuevos dioses o fuerzas míticas sobre las que se vierte el secreto deseo de disponer de ellas (Mardones, 1999: 12).

Tal como ocurrió con el despliegue del protestantismo, la devoción de La Santa Muerte nace ante la lentitud de la Iglesia Católica para adaptarse a los aspectos técnicos de la vida urbana y a su estructura; esto a veces la hace incapaz de responder a las necesidades psicológicas de la gente actual (Mardones, 1999: 17), igual que ocurre con otras sectas. De esta manera vemos que la Iglesia Católica está perdiendo el control sobre el campo religioso y sobre los dioses: "sus desesperadas y redobladas cartas pastorales y encíclicas condenando duramente a las sectas reflejan esta impotencia para contrarrestar una corriente de autonomía religiosa" (Bastian, 1997: 10). Esto se puede observar en este texto:

Ese culto es producto de la ignorancia, la superstición y la idolatría. La Iglesia Católica, desde sus inicios, ha invitado a los fieles a vivir siempre en gracia para cuando llegue la hora final se tenga una muerte sin pecado, una muerte santa. Desafortunadamente, algunas personas se han aprovechado de la semejanza de estas palabras para engañar y decir que la Iglesia siempre ha dado culto a la Santa Muerte. Que no te engañen, no es lo mismo tener una muerte santa que creer y dar culto a la Santa Muerte (Aguilar, 2007: 180).

Pero a los devotos no les importa que les digan que son idólatras, brujos o ingenuos. ${ }^{18}$ La Santa Muerte representa una opción para aquellos que están en busca de la supervivencia, que se enfrentan a la languidez de las normas que la cultura les ha impuesto. Estos devotos, con hogar o sin él, son víctimas ocasionales de crímenes, robos, violaciones, despidos injustificados; se trata de los que quieren cierta seguridad en su negocio, en su vida familiar, escuela o relación sentimental. Son, muchas veces, los olvidados, los marginados, aquellos a los que la sociedad no quiere ver. Individuos que en colectivo se reencuentran, se identifican, crean nuevos lazos de unión, parentesco o ayuda mutua. De esta manera los pobres y marginados (sujetos primordiales del catolicismo popular) creen en Dios, los santos y la muerte porque, de otro modo, "la vida seria insostenible" (González, 2002: 103). 


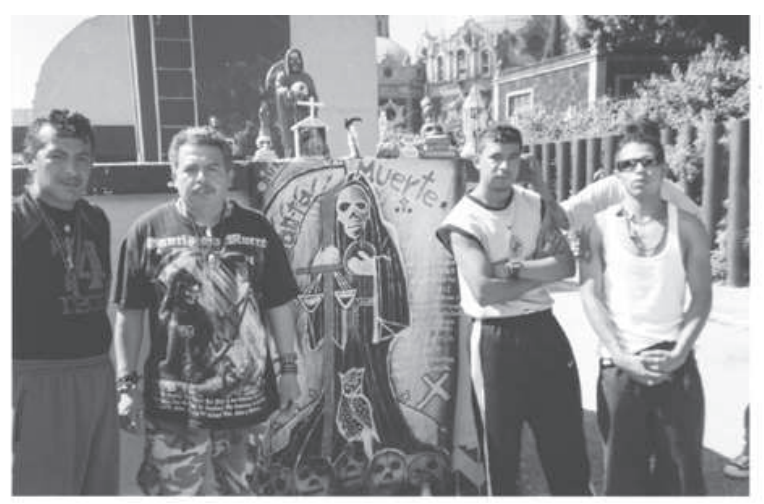

Esta nueva fraternidad creada en la modernidad es el resultado de

Una necesidad del hogar ante el desarraigo a que somete esta sociedad a muchas personas. Recuperaro encontrar un rincón cálido donde cada uno pueda ser acogido y reconocidoes un deseo a voces de muchos en esta sociedad anónima, dura y despiadada (Mardones, 1999: 31).

Tal vez sean éstas las razones de su aparición y expansión por el territorio mexicano. Estos creyentes tienen en común solamente la imagen de La Santa Muerte como justiciera. Con ella se defienden los desvalidos, los inadaptados de la sociedad. Es además percibida como cristiana, tal como se demuestra en la mayoría de las entrevistas: "soy una mujer que salgo con mi muerte con todo el orgullo, con mi Cristo, mi virgen. Soy cristiana y creyente, pero estoy inclinada hacia la muerte, la cual me espera y me llevará".

Este grupo de creyentes ya tiene un reconocimiento ante la sociedad; ${ }^{19}$ sólo exigen de sus miembros tributos simbólicos para La Santa, igual que se hace con los santos cristianos y, ocasionalmente, dependiendo del tipo de "manda", puede haber intercambio con los individuos del grupo: un intercambio del don. En algunos casos el homenaje no sólo se da a "La Santita" sino también al grupo, como puede observarse en algunos rituales asociados con rosarios, misas o fiestas de la propia imagen en los que se reparten flores, estampas, dulces y manzanas a los otros fieles. El protocolo es personal, sin reglas; no se cuestiona quién se es ni lo que se hizo en el pasado. Es por ello que esta religiosidad cuenta con tantos adeptos. "La muerte los acepta como son, no pide cuentas ni mayor explicación". Y ellos a su vez asimilan a la muerte como algo seguro, que es parte de Dios y que está "adentro de uno, siempre nos acompaña". De esta manera, "el hombre individual es un dador de sentido por cuanto su cuerpo configura el mundo, lo recorta según una intencionalidad peculiar, y todo proceso humano es de por sí significativo" (Aisenson, 1981: 103).

\section{Resignificación del Niño Dios casero, una relación simbiótica}

La imagen de Jesucristo en edad adulta o infante está presente en la mayoría de los hogares de los devotos de La Santa Muerte, ya sea en altares domésticos o en un sitio especial. Los devotos se asumen como católicos. Saben que sin Dios no se puede hacer nada; primero hay que pedirle permiso a él y la intermediaria es la propia muerte: "Es el hijo del padre eterno, es muy respetable", se me comentó. De esta manera, Cristo está presente vivo y cotidianamente inmolado por la comunidad de fieles que se sigue comunicando con él, fuente suprema de la vida espiritual (Durkheim, 2001:30).

Para este sector devocional la festividad del Día de la Candelaria no es ajena, como tampoco para los asiduos católicos mexicanos y romanos en el Distrito Federal. La tradición ${ }^{20}$ de tener un Niño Dios en casa es común; se tienen compadrazgos desde la Navidad, tras el arrullo de la imagen, hasta después de partir la rosca de Reyes, el 6 de enero.

Por ejemplo, para doña Blanca, quien se dedica a la fe y devoción de La Santa Muerte, el Niño Jesús "es parte de nuestra fe, devoción y cultura; es el Niño Dios que llega a abrir los caminos para la sobrevivencia del ser humano [...] Desde mis padres siempre ha llegado la alegría a nuestros corazones, desde que lo arrullamos pedimos que nos cambie". 
Lo particular de estos devotos es que resignifican la vestimenta y decoración del Niño Dios, mezclando elementos de la muerte principalmente en dos rubros: la tela del vestido y la presencia de una calavera a la manera del Santo Niño de las Suertes.

Con los restos (altamente cotizados) del paño con que se visten las esculturas de gran formato de La Santa Muerte en algunas capillas, no sólo se adornan pequeñas figurillas de la muerte, sino que también se emplean para vestir a los Niños Dios. De esta manera se comparten con el Niño las dádivas de la muerte. Hay quien me comentó que "se cierra un círculo, en la presencia de Jesús y La Santa, para convencernos más de la presencia de Dios"; una vez que se ha vestido a los Niños se les coloca un cráneo, haciendo alusión a la muerte, y con ello se hace patente la devoción al Niño de las Suertes. Para el señor Martín:

Representa mucho que la presencia del Niño Jesús pueda tener en sus manos un cráneo, eso para mí tiene dos significados muy fuertes, es muy especial. Darle un sentido a la vida de un principio y de un fin de lo que existe, la luz y la oscuridad, lo blanco y lo negro [...] Y en las manos de Jesús está la muerte, el por qué vivir y en lo que vamos a acabar. iVamos a acabar en una calavera! [...] Se reconoce la muerte en el pecado.

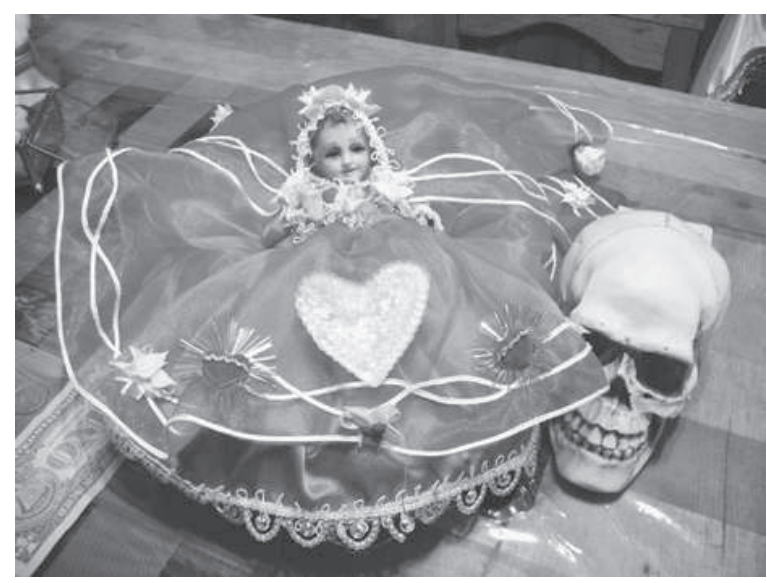

Otra propuesta es que en su advocación pasionista: ${ }^{21}$ "Ve por los niños difuntos, almas en pena que él los va a proteger [...] ellos van a tener un lugar especial con Dios, que Jesús les va a dar esa comprensión, esa ternura, amor [...] Cobija a todos esos niños que mueren". ${ }^{22}$

En otras palabras, los niños tienen el destino de estar protegidos cuando mueren. De esta manera, el símbolo religioso está preñado de contenido humano integral (afirmación, deseo, júbilo, temor, clamor, etcétera); en la misma imagen, es decir calavera-Niño Dios, se participa del mismo poder y ambos íconos se otorgan mutuamente autenticidad. El símbolo mayor (Niño Dios) se acompaña de un signo menor (calavera), que sugiere realidades intermedias o mediaciones que la imaginación necesita y coordina jerárquicamente (Blanch, 1996: 28-29).

Si bien muchos no conocen la historia de la devoción del Niño de las Suertes, la imagen icónica ha sido reinterpretada por los devotos "por el hecho de tener una calavera"; se da cómo un hecho válido, aunque también existe el caso reportado de un señor que regaló a una capilla de La Santa Muerte ${ }^{23}$ la escultura de un Niño Dios vestido como el Niño de las Suertes "en agradecimiento a un favor que la muerte le hizo". Su esposa no podía tener hijos, ya tenían muchos años de casados sin lograrlo, entonces él fue a la capilla de Tacubaya y lo vio, le regalaron una estampita. "Entonces le pidió al Niño de las Suertes que le permitiera a su esposa tener un hijo". Y ahora ya tienen dos hijos. Como podemos ver, en este caso el milagro de la concepción se adjudica tanto a La Santa Muerte como a Jesús infante:

Es interesante observar cómo un objeto cultural, producto de la idiosincrasia del pueblo mexicano, específicamente de la ciudad de México, tiene la magia de producir emociones y sensaciones en los propietarios. El cuerpo de materia inerte, símbolo divino, es un receptáculo de deseos, frustraciones y 
agradecimientos. Por un lado, asociado a las peticiones de las necesidades, problemas y carencias de los devotos y, por otro, el que la imagen genere la ilusión de la maternidad (Perdigón, 2007: 9).

Así, algunos devotos han adoptado esta devoción del Niño de las Suertes para con su niño Dios hogareño como una simbiosis, donde se asocian dos entidades diferentes(lo que he quitado es una definición del diccionario) con el fin de reforzar su creencia, aumentar el poder icónico en una sola esencia. ${ }^{24}$ Nos encontramos ante dos símbolos dominantes con valores que son considerados como fines en sí mismos, que interactúan en un mismo contexto; ambos eficaces en el ritual de la celebración de la Candelaria.

Pero esto no está del todo asegurado. Ante la sospecha del incremento de este fenómeno religioso de ver a los niños Dios a la manera del Niño de las Suertes, un tanto por el temor y otro por el desconocimiento de esta devoción y su historia, los sacerdotes han alertado al alto clero, de tal manera que se dice que:

Hay muchas personas que visten o disfrazan a Jesucristo con atuendos raros o extraños que en muchas ocasiones provienen de ideas distintas o contrarias a la fe [...] En los últimos días han aparecido incluso quienes quieren vestir al Niño Dios con el atuendo de la llamada Santa Muerte, ${ }^{25}$ devoción contraria a la fe católica. Por eso es necesario tener muy claras algunas ideas para que no nos desviemos de nuestra fe o confundamos nuestras ideas (Aguilar, 2007: 1-2).

$\mathrm{Al}$ leerles este fragmento de texto a algunos devotos, el comentario que surgió fue que saben que está mal vestir al Niño como La Santa Muerte, saben que es Dios y que estaría mal ponerle guadaña, una balanza y toda la cosa. "iEs una falta de respeto! iEl Niño Dios va como niño!". Incluso comentaron que ese comunicado es porque "la iglesia sólo quiere opacar, mas no acabará con la devoción de la Santísima Muerte". La Iglesia, sin embargo, acepta que coloquen el cráneo cerca del Niño para bendecirlo, tal como lo tiene el Niño de las Suertes. Aun así, es posible que este acto de colocar la calavera sea interpretado por algunos sacerdotes como vínculo directo con La Santa Muerte y eso en ocasiones, como se ha podido ver, es cierto.

En el trabajo de campo se observó que en el catálogo de modelos de "Niños Uribe"26 de 2007, se muestra y se vende un vestuario blanco con motivos dorados y reemplaza a la calavera con un cetro o un mundo. Esta situación, para las religiosas del convento de San Bernardo, es quizá "por miedo a la calavera [...] tal vez es porque desconocen cómo es el Niño de las Suertes. Esos modelos nada tienen que ver con el significado".

Por lo anterior, infiero que existe una posible estrategia de la curia católica para asesorar a fabricantes de vestidos con tal de cambiar el diseño original, a lo que se suman las pláticas en misa y los comunicados de prensa sobre cómo vestir al Niño. Una devota comenta al respecto:

Lo atribuyo a que no se quieren ver involucrados dentro de la fe y devoción de la Santa Muerte. Pero que no se le olvide algo a esta revista, con todo respeto, que no va a poderlo quitar dentro de la Iglesia, porque así es la tradición. Y el día que la Iglesia quitara al Niño de las Suertes, entonces perdería devotos y más fieles. Porque nosotros, los devotos de La Santa Muerte, ya adquirimos eso, y nadie nos lo va a quitar [...] La revista puede quitar y poner, falta quien lo acepte, pero el devoto y el creyente nunca lo van a quitar. Cambiará de color el vestido pero su cráneo siempre lo va a llevar. iNo se puede cambiar una devoción de años! 


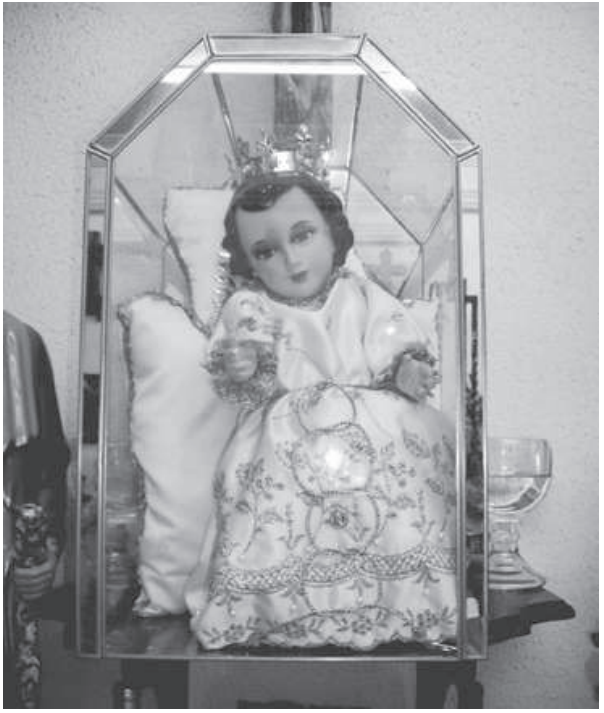

Para los devotos cambiar la iconografía de esta devoción es un acto de la Iglesia Católica mexicana para mermar el culto. Como dice un devoto:

Seguramente es porque la Iglesia dijo a partir de ese momento, le vamos a dar otra significación, vamos a quitarle la calavera. Tal vez porque piensan que en el pasado fue un error ponérsela en su mano, o que la gente puede relacionarlo con La Santa Muerte [...] yo creo que es una acometida de la Iglesia.

El hecho de quitar el cráneo en la indumentaria que se vende al público por parte de las tiendas comerciales no es un freno para los devotos del Niño de las Suertes y de La Santa Muerte; basta con ir a otros comercios, ya sea mercados, tianguis o en la "Romería Tradicional de Niños Dios" (en el centro histórico de la Ciudad de México) para adquirir el vestido "como debe de ir", o simplemente comprar aparte el cráneo y colocarlo junto a la esculturita para llevarlo a bendecir, junto con la vela y las flores.

Otra táctica de los devotos de La Santísima Muerte es vestir a su Niño Dios de otra advocación, ya sea de
"Las Palomas", “Atocha”, “Mueve Corazones”, por citar algunas; pero se le anexa el cráneo ya sea en la mano,, los pies o bien entre las velas, flores o trigo con los que se lleva a bendecir. El objetivo de tanta manipulación simbólica por parte de la feligresía es expresar su sentimiento, su fe; esto es confiar, es el asentimiento firme de la voluntad a una verdad basada únicamente en la revelación divina (Royston, 2005: 187).

\section{Consideraciones finales}

No se sabe desde cuándo o quién inventó la devoción a La Santa Muerte como la conocemos actualmente. Como ícono proviene de Occidente, pero la forma de rezarle externa un arraigo católico popular. Esta religiosidad popular, donde la fe se transmite por los milagros de la entidad, resulta verdadera en tanto que los devotos experimentan su poder y acuden a ella sin importarles que no sea admitida en el circuito oficial del cristianismo mexicano y a pesar de los múltiples riesgos. ${ }^{27}$

Es probable que la característica de este culto sea que suma lo esencial del cristianismo contenido en el Evangelio (no así en la teología) ${ }^{28}$ con las condiciones sociales culturales marginales. Se reinventa en los rituales; es cambiante, se actualiza según las nuevas necesidades, se modifica partiendo de sus líderes o bien por los propios individuos y es capaz de crear moda. Al nacer del pueblo y no de una institución que la fragmente, es parte de una religiosidad popular que se constituye en identidades colectivas locales o regionales. Tal es el caso del área comprendida en el Distrito Federal, zona compleja por el ritmo de vida y por la multiculturalidad.

El caso que se presenta en este texto es un ejemplo de cómo se transforman los rituales para reactualizar el ícono de La Santa Muerte, la manera en que se retroalimentan los devotos y se escabullen de los embates de la curia católica. Se trata de otra manera de mirar su fe y afianzar su creencia.

Con esto se suman a una celebración aceptada, como la de la Candelaria, que recuerda un momento 
histórico en pleno siglo XXI en el que un mito se revive cíclicamente, donde la presencia de las esculturas que representan a Jesús en la infancia son fundamentales en los hogares citadinos. Objeto de culto adquirido vía herencia, compra o regalo, representa la presencia de Dios en las familias tradicionales del Distrito Federal, pero también es un ícono en los hogares de los devotos de La Santa Muerte, sector que se asume como católico. No dejan de creer en Dios porque eso les han enseñado desde la niñez (según entrevistas). Ser devoto de La Santa Muerte es “cambiar para bien, no permitir que me embargue una ira. El verdadero devoto tiene la capacidad de ir en el sendero que Dios nos marcó. La muerte me ha hecho cambiar, ser mejor padre, amigo y hermano".

Este fenómeno captado recientemente es importante, pues ocurre en él un sincretismo religioso en el que varios devotos de La Santa Muerte han tomado la imagen del Niño Dios en la advocación del Niño de las Suertes, por la presencia del cráneo, que es vida y muerte a la vez; de alguna manera asumen que es "cerrar un círculo de fe, ipero con su respeto, amor y devoción a ambos!". Vestir a los niños Dios hogareños verifica este hecho. El ritual de vestir al Niño Dios para el Día de la Candelaria es adecuado por parte de estos feligreses, según sus propios valores axiomáticos. De esta manera ambas deidades son sagradas en sí mismas y complementarias a la vez; son representaciones metonímicas de una realidad: la de los propios devotos de acuerdo con sus necesidades y formas de vida.

Jesucristo y La Santa Muerte son el dualismo con el que se mueven algunos devotos de este culto, pues a ambas entidades se les piden milagros y se les ofrecen dádivas. La imagen del Niño Dios resulta, así vestido, la combinación perfecta de ambas entidades. Esta expresión simbólica y hasta psicológica está fundamentalmente relacionada:

Con las grandes preguntas que el hombre se ha hecho siempre y con lo que nos sucede a niveles profundos: la experiencia del dolor, del sufrimiento, la muerte propia y la de los seres queridos, la necesidad de consuelo, reconocimiento y de sentido de pertenencia pero, sobre todo, con la esperanza en que no todo acaba con la muerte (Inestrosa, 2001: 18).

Para las religiosas de Tacubaya, este sector de devotos de La Santa Muerte lleva a vestir a sus niños como Niño de las Suertes "por falta de cultura, por ignorancia. iCómo pueden confundir las cosas! Es desconocer la fe ante el significado de la calaverita". Para cierto grupo de estos devotos, con esta imagen y a través de la muerte se van acercando a Dios. "iNosotros no inventamos nada, simplemente tomamos el Niño Dios representando lo que representa a los devotos de La Santa Muerte!"

Aunque se trate de cambiar la vestimenta original de este Niño Dios en los circuitos comerciales apoyados por la curia, simplemente es demasiado tarde; el sincretismo ya se ha dado. A los niños de los hogares de estos devotos se les viste con elegancia, hay respeto y fe, devoción a La Santa Muerte, pero en una sola imagen: el Niño de las Suertes.

\section{Notas}

${ }^{1}$ De liturgia. Orden y forma determinados por la Iglesia Católica Romana para la celebración de oficios.

${ }^{2}$ A los cuarenta días del nacimiento de su hijo, nuestro Señor se dirigió al templo para cumplir con la Ley mosaica. Los misterios de la Presentación del Hijo y de la Purificación de la Madre están unidos en la liturgia de la misa. La Santísima Virgen quiso cumplir lo que estaba dispuesto, aunque era la "llena de gracia". A lo largo de los siglos ha sido considerada como fiesta del Señor o como una fiesta mariana. Se celebraba ya en Jerusalén en el siglo IV, y desde ahí se extendió por oriente y occidente. En Roma y en Galia (Francia) tuvo carácter penitencial y se hacía la procesión con velas que se bendecían, de ahí que se llame también la "Candelaria". La procesión con los cirios encendidos significa la luz de 
Cristo anunciada por Simeón. En algunos lugares es el día fijado para "levantar al niño", es decir, quitar el nacimiento, con lo que se clausuran las solemnidades de la Epifanía o Manifestación del Señor (Socías, 1998).

${ }^{3}$ El culto, en el contexto de la fiesta, se convierte en apoteosis que rompe la monotonía cotidiana y coloca a la comunidad en una especie de "tiempo liberado" de corta duración (González, 2002: 76).

${ }^{4}$ Al decir "niño Dios" nos referimos a las esculturas de yeso, madera o resina que representan a la Santa Infancia o Jesús infante.

${ }^{5}$ La palabra "niño" con minúsculas designa a los infantes de carne y hueso que tienen las familias mexicanas.

${ }^{6}$ La fiesta de los Reyes Magos, que se celebra el 6 de enero, es un día especial en México porque tiene múltiples significados. Recuerda la adoración de Jesús infante por parte de los Reyes, se trata de una conmemoración medular en la liturgia católica. También es el día en que aparece la deliciosa Rosca de Reyes, reina esperada en la merienda familiar. Se trata de un pan donde está escondida una figurilla que representa al Hijo de Dios. Cuenta la tradición que la rosca refiere el ocultamiento del Niño Dios para que Herodes no lo encuentre como lo hizo con los santos inocentes (cuya celebración es el 28 de diciembre); de esta manera el pan resguarda a Jesús, representado en la figura de plástico. El cuchillo personifica a Herodes de Antipaz.

Quien encuentra a Jesús paga a los otros comensales los tamales y el atole para el 2 de febrero. Algunos adquieren una obligación (generalmente el primero que saca la imagen, pues actualmente hay por lo menos tres figuras escondidas), pues se convierten en madrina o padrino de vestido del Niño Dios de la casa donde se partió la rosca. En esta celebración de Epifanía es cuando se levanta al Niño Dios del pesebre, sale del contexto del Misterio y el padrino o madrina, ya sea aquel que lo arrulló la Nochebuena o quien sacó la imagen en la rosca, tiene que llevar a restaurar y vestir al cuerpo de Jesucristo representado en escultura.
${ }^{7}$ Tal es el caso de la fábrica "Niños Uribe", en la calle de Talavera, en el centro histórico de la Ciudad de México.

${ }^{8}$ Se trata de álbumes con recortes de revistas, fotografías y estampas, o de alguna revista especializada que se vende en los puestos de periódico.

${ }^{9}$ Respecto a la indumentaria, la Iglesia expone que es mejor vestir a Cristo con alguna de sus advocaciones: de Nazareno, de Sagrado Corazón, de Cristo Rey, de Cristo Sacerdote, etcétera. No es correcto seguir ocurrencias o modas. Algunas personas pretenden cometer abusos y vestir a la imagen como charro o de traje con corbata, etcétera (Aguilar, 2007: 162).

${ }^{10} \mathrm{Su}$ nombre se debe a su milagrosa aparición entre las yerbas, en el camino hacia Tlalpan, donde luego brotó un manantial al que se conoció como "Ojo del Niño"; también se debe a que los religiosos que lo encontraron sortearon entre varios conventos el destino final de la escultura; el afortunado fue el Convento de San Bernardo de la Orden de la Concepción. Tras este evento se le dio el nombre a esta santa figura como El Santo Niño de las Suertes porque era una verdadera suerte que tocara gracia dos veces a un convento. Actualmente es esta misma congregación la que tiene esta imagen para el culto público.

${ }^{11}$ Los Evangelios Apócrifos del Nuevo Testamento tienen la finalidad de dar a conocer la vida y doctrina terrestre de Jesús y sus antecedentes familiares; se arrogan a la autoridad de los evangelios canónicos sin que, a pesar de ello, la Iglesia los haya incluido oficialmente en su canon (Santos de Otero, 1999: 3). Estos documentos desempeñaron un papel importante, pues ayudaron a múltiples artistas a realizar obras plásticas para "llenar los vacíos" de los evangelios canónicos en relación con los detalles en la vida y mensaje de Jesús; con esto se facilitaba que el pueblo sencillo entendiera la religión.

${ }^{12}$ Cuando nos referimos al convento de San Bernardo se trata del convento femenino, cuya fundación data de la Colonia. Nada tiene que ver con la imagen esqueletizada de san Bernardo ubicada en Tepatepec, Hidalgo, 
que es una escultura de madera posiblemente de fines del siglo XVIII que representa el triunfo de la Cruz sobre la muerte y a la que se le rinde culto en una capilla casera otomí.

${ }^{13}$ Popular puede ser entendido como aquello que se genera en el pueblo o lo que éste asume y modifica al apropiárselo. Hablamos de "pueblo" no en su acepción etnológica de comunidad cultural, ni política, sino como categoría sociológica; es la parte mayoritaria de la población constituida por los actores sociales que, con su actividad productiva, mantienen y reproducen la sociedad, y son agentes de cambio (Quezada, 2004: 31). La religiosidad popular (de las peregrinaciones, los cultos de los santos y otras formas de superstición) es ante todo expresión de sociabilidad. Más que la pureza de la doctrina, es el vivir o sobrevivir juntos lo que preocupa a las comunidades de base (Maffesoli, 1990: 113).

${ }^{14}$ Tomando en cuenta que la religión llegada a América como parte de la conquista tenía fuertes rasgos medievales (con influencias moriscas y judaizantes y, por lo tanto, creencias mágico-supersticiosas).

${ }^{15} \mathrm{Tal}$ es el caso del uso de listones para hacer pedimentos, como se hace actualmente con San Charbel.

${ }^{16}$ Entre los principales líderes espirituales en el Distrito Federal está Manuel Valadez; por herencia familiar se autodenomina curandero y desde hace años atiende en el Mercado de Sonora; él es el principal proveedor de oraciones y rituales relacionados con los diversos males que aquejan a los hombres. Doña Enriqueta, en Tepito, es la primera que abrió el culto a la calle y colocó una imagen de grandes proporciones, espacio famoso donde se celebran rosarios dedicados a esta imagen. David Romo, religioso de la Iglesia Católica Tradicional México-Estados Unidos, otorga a las oraciones un carácter más apegado con lo católico, le da a La Santa Muerte un estatus de ángel. Originalmente estaba más separado de la brujería, pero ha dado otro giro hacia la santería, de tal forma que otorga carne y color al esqueleto asociándolo con Yemayá de manera disimulada ante los devotos. A estos personajes se suman múltiples curanderos, brujos, espiritistas, chamanes, cartomantes, rezanderos o simples devotos que han colocado capillas públicas. Todos ofrecen su sabiduría, apoyo espiritual y diversos productos a los necesitados.

${ }^{17}$ Estos son términos usados en las entrevistas por los devotos de La Santa Muerte.

${ }^{18}$ Como han sido tachados por la Curia.

${ }^{19}$ Toda religión instituye su propia ritualidad y se constituye como institución encargada de celebrar la rememoración, la conmemoración del pacto personal y comunitario con la divinidad. Es decir, toda religión se constituye como el ámbito y el espacio de ritualidad que permite a los devotos confesarse fieles ente la divinidad y asumirse como miembros de una comunidad ritual, de culto (Inestrosa, 2001: 9).

20 "Toda tradición se basa en lo que una historia estructural ha acumulado como obvio, como regular, como estable, y la reflexión que permite ver lo obvio sólo opera con lo que perturba esa regularidad" (Maturana y Varela, 1984: 162).

${ }^{21}$ A las imágenes de Jesús infante que tienen una cruz, corona de espinas o que duermen sobre un cráneo de calavera se les llama "pasionistas"; constituyen una alusión directa al futuro sacrificio de Cristo, una manera de subrayar que su destino es haber nacido para morir y salvar a la humanidad.

${ }^{22}$ En este comentario la imagen del Niño Dios se asocia con los angelitos o niños difuntos. Según la tradición cultural católica se refiere a los que murieron después de bautizados y antes de tener "uso de razón". Así, la palabra "angelito" pone de manifiesto, por un lado, la pureza extrema de este pequeño ser, libre ya de pecado original por el bautismo recibido; por otro, la firme convicción de que el niño, debido a su corta edad, entrará de inmediato en el Paraíso (Aceves, 1992: 27-28).

${ }^{23}$ Se trata de Esperanza, ubicada en Ferrocarril de Cintura, colonia Morelos, centro histórico de la Ciudad de México. ${ }^{24}$ De esta manera también se da un camuflaje a su creencia, se lleva a bendecir su escultura de Niño Dios sin que el sacerdote se dé cuenta. 
${ }^{25}$ En trabajo de campo relacionado con el tema de vestir al Niño Dios para la celebración de la Candelaria, al realizar entrevistas, los sacerdotes comentaron que hasta la fecha no han encontrado la vestimenta a la manera de La Santa Muerte, pero sí relacionada con el Niño de las Suertes; algunos expresaron que si esto ocurriera platicarían con las personas para sacarlas de malos entendidos, no necesariamente como reprimenda sino a manera de conducción para tener un buen culto y no incurrir en pecado.

26 "Niños Uribe" es una tienda que sólo se dedica a la fabricación, venta y distribución de vestidos de niños Dios; además de ser una empresa prototipo en relación con esta mercancía, es la que dicta la moda anualmente para la festividad de la Candelaria y, según entrevistas, tiene asesoría directa de los sacerdotes.

${ }^{27}$ América Latina no es sólo receptora de nuevos movimientos religiosos de origen foráneo; es también creadora de nuevos movimientos que a su vez, siguiendo pautas de internacionalización, exportan sus modelos y creencias (Bastian, 1997: 82).

${ }^{28}$ Se entiende por teología cristiana lo que incluye al dogma (doctrina), moral (ética) y pastoral (cuidado de las almas).

\section{Bibliografía}

Aceves, Gutierre, 1992, "Imágenes de la inocencia eterna”, en El arte ritual de la muerte niña, Artes de México, núm. 15, primavera, México, pp. 27-50.

Aguilar Valdés, José de Jesús, 2006, “¿Cómo visto a mi Niño Dios?", en Desde la Fe, Semanario Católico de información, Arquidiócesis Primada de México, México.

—, 2007, La presentación al Templo o Purificación de María, Guía para medios de comunicación, Arquidiócesis Primada de México, México.

—, 2007, Pregúntale al Padre José, él responde a todas tus dudas, Diana, México.

Aisenson A., 1981, Cuerpo, persona, filosofía y psicología del cuerpo vivido, Fondo de Cultura Económica, México.
Almudena, Hernando, 2002, Arqueología de la identidad, Akal, Madrid.

Bastian, Jean Pierre, 1997, La mutación religiosa de América Latina, FCE, México.

Blanch, Antonio, 1998, Lo estético y lo religioso: cotejo de experiencias y expresiones, Cuadernos de Fe y Cultura, Universidad Iberoamericana-ITESO, México.

Durkheim, Émile, 2001, Las formas elementales de la vida religiosa, ediciones Coyoacán, México.

Eliade, Mircea, 1994, Lo sagrado y lo profano, Colección Labor, Colombia.

Gélis, Jacques, 2005, "El cuerpo, la Iglesia y lo sagrado", en Corbin, Alain y Jean Jacques (coordinadores), Historia del cuerpo, Taurus, Madrid.

Gemo, Fabio y Gioia Lanzi, 1998, "Los componentes rituales", en Giurati, Paolo y Elio Masferrer, No temas... yo soy tu madre. Estudios socioantropológicos de los peregrinos a la Basílica, P y V y CRSR, México.

González M, José Luis, 2002, Fuerzay Sentido, Dabar, México. Inestrosa, Sergio, 2001, La religión como mediadora del sentido de la vida, Cuadernos de Fe y Cultura, Universidad Iberoamericana-ITESO, México.

Kristeva, Julia, 1990, "El Cristo muerto de Holbein", en Feher, Michael et al, Fragmentos para una historia del cuerpo humano, Taurus, España.

Maccono Salesiano, Fernando, 1941, Breve tratado de la sagrada liturgia, Luis Gili, Barcelona.

Mardones, José M., 1999, Nueva espiritualidad. Sociedad moderna y cristianismo, Cuadernos de fe y cultura, Universidad Iberoamericana-ITESO, México.

Maffesoli, Michael, 1990, El tiempo de las tribus, Icaria, Barcelona.

Maturana H y Francisco Varela, 1984, El árbol del conocimiento. Las bases biológicas del entendimiento humano, Lumen, Argentina.

Monterrosa, M y Leticia Talavera, 2006, "Algunas representaciones del Niño Jesús en el arte mexicano”, en Sánchez C. María Eugenia y Delia Salazar (Coordinadores), Los niños: su imagen en la historia, INAH, México, pp. 41-53.

66 Revista LiminaR. Estudios sociales y humanísticos, año 6, vol. VI, núm. 1, junio de 2008, Tuxtla Gutiérrez, Chiapas. ISSN: 1665-8027 
Morín, Edgar, 2005, El paradigma perdido, Kairós, Barcelona. Perdigón C, Judith K., 2002, "La Santísima Muerte”, en Antropología. Boletín oficial del Instituto Nacional de Antropología e Historia. Viejas y nuevas religiosidades, núm. 68 , octubre-diciembre, INAH, México, pp. 36-43.

- 1999, "Los que curan a los santos. Un estudio antropológico de los restauradores del centro Churubusco y su relación con los objetos de culto", en Tesis de maestría, ENAH, México.

—, 2007, "A imagen del hijo, presencia de Dios" (ponencia), en Memorias del II Congreso internacional de antropo logía desde la frontera sur, Universidad de Quintana Roo, Chetumal.
Quezada, Noemí, 2004, Religiosidad popular en México y Cuba, UNAM-PyV, México.

Rostas, Susana y Andrée, Droogers, 1995, "El uso popular de la religión popular en América Latina”, en Cosmovisión, sistema de cargos y práctica religiosa, Alteridades, UAM, año 5, núm. 9, México.

Royston Pike, Edgar, 2005, Diccionario de Religiones, FCE, México.

Santos de Otero, A., 1999, Los evangelios apócrifos, Biblioteca de Autores Cristianos, Madrid.

Socías, James, 1998, Misal Romano Diario, Midwest Theological Forum, Estados Unidos.

Turner, Víctor, 1980, La selva de los símbolos, Siglo XXI, España. 